\title{
Novel BAP degradation pathway during adventitious caulogenesis in Pinus pinea L. cotyledons
}

\author{
Ondrej Novak ${ }^{1 *}$, Candela Cuesta ${ }^{2}$, Karel Dolezal ${ }^{1}$, Lucie Szucova ${ }^{1}$, Lukas Spichal $^{1}$, Belen Fernandez ${ }^{2}$, Ana Rodriguez ${ }^{2}$ \\ , Miroslav Strnad ${ }^{1}$
}

From IUFRO Tree Biotechnology Conference 2011: From Genomes to Integration and Delivery Arraial d'Ajuda, Bahia, Brazil. 26 June - 2 July 2011

\section{Background}

Cytokinins (CKs) are a group of phytohormones which probably regulate the growth, development, and metabolism of all plants. The aromatic CK benzyladenine (BA) has been widely applied in in vitro culture for inducing shoot organogenesis. Our study of endogenous cytokinin profiles during the caulogenic process based on mature cotyledons of stone pine (Pinus pinea L.) showed a novel metabolic pathway of aromatic cytokinins based on modification of purine skeleton.

\section{Methods}

Three-year-old mature seeds from two half-sibling selected families and open-pollinated trees of $P$. pinea were used [1] and the samples were collected following the Alonso et al.[2] procedure. Extraction and purification of cytokinins was based on the method described by Novák et al. [3], including modifications published later [4]. The samples were purified using a combination of a cation (SCX-cartridge) and anion [DEAE-Sephadex/ C18-cartridge] exchangers. Combination of high performance liquid chromatography (HPLC) with quadrupoletime of flight mass spectrometry (QqTOF) was used for accurate and sensitive identification and quantification of cytokinins.

\section{Results and discussion}

Cortizo et al. [5] published the dynamics of BA uptake and metabolism in P. pinea cotyledons excised from

\footnotetext{
* Correspondence: ondrej.novak@upol.cz

'Laboratory of Growth Regulators, Faculty of Science, Palacky University \& Institute of Experimental Botany AS CR, Slechtitelu 11, Olomouc, CZ-783 71, Czech Republic

Full list of author information is available at the end of the article
}

embryos precultured for 2 and 4 days and cultured in vitro in modified Le Poivre media with $4.4 \mu \mathrm{M}$ BA. In our experiment, we used $44.4 \mu \mathrm{M}$ concentration of BA and samples were collected at different periods $(0 ; 1 ; 2$; 6; 16; $24 \mathrm{~h}$ and 2; 4; $6 \mathrm{~d}$ ). Using high-resolution MS, the naturally-occurring BA metabolites as well as new BA forms were identified. In comparison with previously published profiles of the BA metabolite pool [5,6], the ribosyl and glycosyl forms were quantified as the most abundant metabolites. Moreover the biological activity of identified BA and its derivatives were compared in various $C K$ bioassays. The results indicate that $\mathrm{BA}$ uptake during the caulogenic process may be possible to regulate not only by known cytokinin pathways. Finally, the feeding experiment with stable isotope-labelled standard, ${ }^{15} \mathrm{~N}_{4}$-BA, confirmed our identification of the novel metabolic CK pathway.

\section{Conclusions}

The identification of the novel BA forms demonstrates that the novel cytokinin pathway is used as a control mechanism of BA uptake from the bud induction medium during adventitious caulogenesis in cotyledons of $P$. pinea. Our results help to understand the processes associated with embryo germination in plant tissue culture.

\footnotetext{
Author details

${ }^{1}$ Laboratory of Growth Regulators, Faculty of Science, Palacky University \& Institute of Experimental Botany AS CR, Slechtitelu 11, Olomouc, CZ-783 71 , Czech Republic. ${ }^{2}$ Area de Fisiologia Vegetal, Departamento Biologia de Organismos y Sistemas, Instituto de Biotecnologia de Asturias, Universidad de Oviedo, Oviedo, E-33071, Spain.
}

Published: 13 September 2011 


\section{References}

1. Cuesta C, Ordas RJ, Fernandez B, Rodriguez A: Clonal micropropagation of six selected half-sibling families of Pinus pinea and somaclonal variation analysis. Plant Cell Tiss. Org 2008, 95:125-130.

2. Alonso P, Moncalean P, Fernandez B, Rodriguez A, Centeno ML, Ordas RJ: An improved micropropagation protocol for stone pine (Pinus pinea $\mathrm{L}$.). Ann. Forest Sci 2006, 63:879-885.

3. Novak O, Tarkowski P, Tarkowska D, Dolezal K, Lenobel R, Strnad M: Quantitative analysis of cytokinins in plants by liquid chromatography/ single-quadrupole mass spectrometry. Anal. Chim. Acta 2003, 480:207-218.

4. Novak O, Hauserova E, Amakorova P, Dolezal K, Strnad M: Cytokinin profiling in plant tissues using ultra-performance liquid chromatography-electrospray tandem mass spectrometry. Phytochem 2008, 69:2214-2224.

5. Cortizo M, Cuesta C, Centeno ML, Rodriguez A, Fernandez B, Ordas RJ Benzyladenine metabolism and temporal capacity of Pinus pinea $\mathrm{L}$. cotyledons to form buds in vitro. J Plant Physiol 2009, 166:1069-107.

6. Zhang $\mathrm{H}$, Horgan $\mathrm{K}$, Reynolds PHS, Jameson PE: Benzyladenine metabolism during reinvigoration of mature Pinus radiate buds in vitro. Tree Physiol 2010, 30:514-526.

doi:10.1186/1753-6561-5-S7-P143

Cite this article as: Novak et al:: Novel BAP degradation pathway during adventitious caulogenesis in Pinus pinea L. cotyledons. BMC Proceedings 2011 5(Suppl 7):P143.

\section{Submit your next manuscript to BioMed Central and take full advantage of:}

- Convenient online submission

- Thorough peer review

- No space constraints or color figure charges

- Immediate publication on acceptance

- Inclusion in PubMed, CAS, Scopus and Google Scholar

- Research which is freely available for redistribution

Submit your manuscript at www.biomedcentral.com/submit 